\title{
Rooting of yerba mate \\ cuttings with different lengths
}

Manoela Mendes Duarte', Maria Cecília Mireski', Afonso Oliszeski², Ivar Wendling ${ }^{3}$, Carlos André Stuepp ${ }^{4}$

I Federal University of Paraná, Botanical Garden Campus. Curitiba, Paraná, Brasil.

E-mail: manu.florestal@gmail.com, mariacecilia.agro@gmail.com

2 Chimarrão Bitumirim Ind. de Erva-Mate Ltda. Vila Nova Farm, Ivai, Paraná, Brasil.

E-mail: afonsooliszeski@hotmail.com

${ }^{3}$ Brazilian Agricultural Research Corporation (Embrapa Florestas), Colombo, Paraná, Brasil.

E-mail: ivar.wendling@embrapa.br

${ }^{4}$ State University of Ponta Grossa, Uvaranas Campus. Ponta Grossa, Paraná, Brasil.

E-mail: castuepp@uepg.br

Received in 15 jul. 2018 . Accepted at: 7 dez. 2018. DOI: http://dx.doi.org/ I0.2 I674/2448-0479.5 I.05-I I

\begin{abstract}
Due to its economic, social, and ecological potential, llex paraguariensis is considered one of the most important native forestry species in southern Brazil, needing high production of quality plants to supply consumption. Therefore, vegetative propagation is a key technique since it enables plants production with higher standard and genetic quality. Several studies have focused on defining appropriate methods for rooting yerba mate cuttings, even though the overall rooting indexes are not yet considered appropriate. Thus, the objective of this study was to evaluate the rooting, root and aerial vigor of yerba mate cuttings and determine the best cuttings length for formation of clonal plants. Twenty parent trees were pruned and after five months epicormic sprouts were collected to prepare stem cuttings with lengths of $2 \pm 0.2 \mathrm{~cm}, 4 \pm 0.2 \mathrm{~cm}, 6 \pm 0.2 \mathrm{~cm}, 8 \pm 0.2 \mathrm{~cm}, 10 \pm 0.2 \mathrm{~cm}$ and $12 \pm 0.2 \mathrm{~cm}$ and diameter of $0.5 \pm 0.2 \mathrm{~cm}$. We planted cuttings in plastic boxes filled with substrate based on carbonized yerba mate matchsticks and vermiculite. After 120 days we evaluated the percentage of rooting, number of roots per cutting, average length of the 3 largest roots per cutting, cuttings with callus, cuttings with roots and callus, mortality, sprouts emission, and leaf maintenance. Our results show that rooting and vigor of roots in yerba mate stem cuttings are influenced by cuttings length, being $10 \mathrm{~cm}$ cuttings the most efficient for clonal propagation of the species.
\end{abstract}

Keywords: Vegetative Propagation. Native Forest Species. Ilex paraguariensis.

\section{Resumo}

\section{Enraizamento de estacas de erva-mate com diferentes comprimentos}

Devido ao seu potencial econômico, social e ecológico, llex paraguariensis é considerada uma das espécies nativas de maior importância na cadeia produtiva florestal da região sul do país, havendo a necessidade de intensa produção de mudas de qualidade para suprir o consumo. Assim, a produção de mudas por propagação vegetativa se configura como técnica chave, posssibilitando a obtenção de mudas com maior padrão de qualidade genética, além da uniformidade. Uma série de estudos foram feitos visando a definição de metodologias adequadas para o enraizamento de estacas de erva-mate, embora os índices gerais de enraizamento ainda não sejam considerados adequados. Assim, objetivou-se no presente estudo avaliar o enraizamento, vigor radicial e vegetativo de estacas de erva-mate e determinar o seu melhor comprimento para a formação de mudas clonais da espécie. Para a realização do estudo, 20 árvores matrizes foram podadas e após cinco meses foram coletadas brotações epicórmicas para confecção de estacas semilenhosas com $2 \pm 0,2 \mathrm{~cm}, 4 \pm 0,2 \mathrm{~cm}, 6 \pm 0,2 \mathrm{~cm}, 8 \pm 0,2 \mathrm{~cm}, 10 \pm 0,2 \mathrm{~cm}$ e $12 \pm 0,2 \mathrm{~cm}$ de comprimento e com diâmetro de $0,5 \pm 0,2 \mathrm{~cm}$. 0 plantio foi realizado em caixas plásticas preenchidas com substrato a base de palito de erva-mate carbonizado e vermiculita. Após I 20 dias foram avaliadas a porcentagem de enraizamento, número de raízes por estaca, comprimento médio das 3 maiores raízes por estaca, estacas com calos, estacas com raízes e calos, mortalidade, 
emissão de brotação e manutenção de folhas. Os resultados demonstram que o enraizamento e vigor de raízes em estacas caulinares de erva-mate são influenciados pelo comprimento das estacas, sendo o comprimento de $10 \mathrm{~cm}$ o mais eficiente na propagação clonal da espécie.

Palavras-chave: Propagação Vegetativa. Espécie Florestal Nativa. Ilex paraguariensis.

\section{Introduction}

Native from South America, Ilex paraguariensis A.St.-Hil. or yerba mate is traditionally consumed as a tonic and stimulant drink, known as mate tea, "chimarrão" or "tererê" (VIDOR et al., 2002). Yerba mate is considered the main non-timber forest product in southern Brazil, and its economic, social, and ecological potential make this species an excellent option for employment and income, especially for small farmers.

Of the non-timber products, yerba mate production grew by $1.7 \%$ in 2016 compared to 2015 , reaching around 347 thousand tons and the second highest production value of $R \$ 398.8$ million (IBGE, 2016). On the other hand, the cultivated yerba mate in 2016 occupied an area of 77 thousand hectares, producing about 616 thousand tons and a production value reaching R\$ 54I.I million (IBGE - PAM, 20I6). Due to yerba mate's diverse uses it has attracted much interest throughout the world, especially for development of new products derived from this species, increasing its export to $11 \%$ in 2016. The main importers of this raw material from Brazil are Uruguay (87.9\%), Chile (3.8\%), Germany (2.7\%), United States (2.5\%), and France (I.3\%) (MDIC, 20I6).

Yerba mate's economic importance, along with increased exportation demands, has caused a new growth cycle for the crop, generating a greater interest in replacing older and less productive plants with new ones that meet productivity expectations and standards required by the world market. Therefore, it is fundamental that yerba mate is cultivated with plants of high genetic, physiological, and sanitary quality to generate productive plants with high standard of raw material.

The most popular form of propagation for yerba mate is through seedlings, however, mature fruits contain about $99 \%$ immature embryos, making germination irregular, slow, and often low (FOWLER et al., 2007). These limitations can be minimized, or even eliminated, by producing clonal plants from genetically superior individuals (BRONDANI et al., 2009).

Recently, llex paraguariensis was included on the list of native species with potential for clonal forestry (WENDLING; BRONDANI, 20I5; SANTIN et al., 20I5; STURION et al., 20I7). Even though this technique is still being evaluated in the field, it has shown promising results (SANTIN et al., 20I5), indicating that clonal plants produced by cuttings and mini-cuttings present higher survival and productivity (leaves and thin branches up to $7 \mathrm{~mm}$ ) rates compared to seedlings (RAKOCEVIC et al., 2006; SANTIN et al., 2015), and that this species has a high potential for clonal propagation.

Given the success of these results, more studies seeking to improve yerba mate cuttings techniques are needed. One factor that can directly influence the rooting and clonal plants formation is the length of cuttings. Studies developed for different species have shown that the length of the cutting seems to be characteristic and specific for each species (FOSTER et al., 2000; OLIVEIRA et al., 2008).

The objective of this study was to evaluate the rooting, root and aerial vigor of yerba mate cuttings and determine the best cuttings length for formation of clonal plants.

\section{Material and Methods}

The experiment was carried out between July and October 2017, on the Bitumirim Ind. de Ervamate Ltda. Company, in Ivaí, PR, Brazil (25'/'8.64 "S and 50'49'I3.29", $750 \mathrm{~m}$ ). The climate of the region is Cfa type, characterized as subtropical, with average temperature of the coldest month below $18{ }^{\circ} \mathrm{C}$ (mesothermic) and average temperature of the warmest month above $22^{\circ} \mathrm{C}$. This climate type presents hot summers, infrequent frosts, and rainfall concentrated in the summer months. However, there is no defined dry season, with annual rainfall around $\mathrm{I}, 500 \mathrm{~mm}$ and water surplus varying from 500 to $800 \mathrm{~mm}$. To produce propagules, we used 20 parent plants of yerba mate trees ( $>50$ years old) planted beneath the understory of Mixed Ombrophilous Forest and pruned at a height of approximately $1.5 \mathrm{~m}$ in February 2017. 
After five months, we collected epicormic sprouts, which we moistened, conditioned in a thermal box, and transported to a covered environment. From these, we prepared semi-hardwood stem cuttings with $2 \pm 0.2 \mathrm{~cm}, 4 \pm 0.2 \mathrm{~cm}, 6 \pm 0.2 \mathrm{~cm}, 8 \pm 0.2 \mathrm{~cm}, 10 \pm 0.2 \mathrm{~cm}$ and $12 \pm 0.2 \mathrm{~cm}$ lengths and diameter of $0.5 \pm 0.2$ $\mathrm{cm}$. A bevel cut was made at the base and directly above the last bud of the cutting, maintaining one leaf on the terminal portion and reducing it to $50 \%$ of its original surface. To plant the cuttings, we used plastic boxes filled with substrate based on carbonized yerba mate matchsticks and vermiculite (I: I v/ v). The bases of cuttings were planted about $\mathrm{I} \mathrm{cm}$ deep and kept in an acclimatized greenhouse with intermittent misting (temperature between $20-30{ }^{\circ} \mathrm{C}$ and relative humidity higher than $80 \%$ ).

After 120 days, we evaluated the following variables: rooting percentage (alive cuttings with roots of at least $2 \mathrm{~mm}$ lenght); percentage of mortality (cuttings that were found with necrotic tissues); percentage of cuttings with callus (alive cuttings, without roots, with undifferentiated cell mass formation at the base); percentage of cuttings with roots and callus (live cuttings with roots of at least $2 \mathrm{~mm}$ in length and formation of undifferentiated cell mass on the base); percentage of sprouts emission (cuttings with emission of new sprouts with at least $2 \mathrm{~mm}$ ); maintenance of original leaves in the cuttings (cuttings that kept the original leaves in the rooting environment); number of roots per cutting, and average length of the three largest roots/cutting $(\mathrm{cm})$.

The experiment was carried out using a completely randomized design, with six treatments (cutting lengths) and four replications, containing 20 cuttings per experimental unit. The variances of the treatments were evaluated for homogeneity using the Bartlett test, and variables that presented significant differences from the $\mathrm{F}$ test had their means compared by the Tukey test at a $5 \%$ probability level. For the analyzes the ASSISTAT computational application was used (SILVA; AZEVEDO, 2009).

\section{Results an Discussion}

The results of the variance analysis for percentage of rooted cuttings, number of roots, average root length, callus presence, cuttings with roots and callus, mortality, sprouts emission, and leaf maintenance in yerba mate cuttings showed significant differences between the studied treatments (Table I).

\section{Table I}

Summary of the variance analysis for the percentage of llex paraguariensis rooted cuttings (RC), number of roots per cutting (NR), average root length (ARL), callus (C), cuttings with roots and callus (CRC), mortality (M), sprouts (S) and maintained leaves (LM) in relation to cuttings length at I 20 days after planting.

\begin{tabular}{|c|c|c|c|c|c|c|c|c|c|}
\hline \multirow{2}{*}{ S.V. } & \multirow{2}{*}{ D.F. } & \multicolumn{8}{|c|}{ Middle square } \\
\hline & & RC (\%) & NR (n) & ARL (cm) & C & CRC & M (\%) & $\mathbf{S}$ & LM \\
\hline $\mathrm{CL}$ & 5 & 2263,54 *** & $12,79 * *$ & $0,6242 *$ & $2162,50 * *$ & $2503,50 * *$ & $31,88 * *$ & $739,38 * *$ & $126,88 * *$ \\
\hline Residual & 18 & $|04,5|$ & 1,56 & 0,181 & 79,86 & 97,57 & 7,29 & $\mid 44,1$ & 25,35 \\
\hline Total & 23 & - & - & - & - & - & - & - & - \\
\hline C.V. (\%) & - & 17,72 & 32,63 & 24,33 & 22,34 & 18,03 & 144,02 & 36,24 & $5,4 I$ \\
\hline
\end{tabular}

S.V.: Source Variation; CL Cutting length (\%); C.V. (\%): Variation coefficient; D.F.: Degrees of freedom; ** Significant to $1 \%$ probability; * Significant to $5 \%$ probability.

Several studies have recommended using semi-hardwood stem cuttings with length patterns of $12 \mathrm{~cm}$ and a pair of leaves above the last bud (BITENCOURT et al., 2009; STUEPP et al., 2015, 2017a, 2017b). However, we question the lack of papers that corroborate information regarding cuttings smaller than $12 \mathrm{~cm}$ and their respective rhizogenic potential, seeing a great discrepancy in studies carried out to date regarding the influence of juvenility and vigor of propagules (BITENCOURT et al., 2009; STUEPP et al., 2015, 2017a, 2017b).

Overall, the stem cuttings used in this study were satisfactory for yerba mate, as observed by other authors (KRATZ et al., 20I5; TRONCO et al.; 20I5; STUEPP et al., 2015, 2017a, 20I7b). The percentage of rooted cuttings ranged from $22.50 \%$ to $86.25 \%$ among the different treatments. Cuttings with $10 \mathrm{~cm}$ formed the most roots, with approximately $86 \%$ rooted cuttings, which was statistically superior to the other lengths, except $2 \mathrm{~cm}$ and $4 \mathrm{~cm}$ (Table 2). 
Average percentages of llex paraguariensis rooted cuttings (RC), number of roots per cutting (NR), average root length (ARL), callus (C), cuttings with roots and callus (CRC), mortality (M), sprouts (SC) and maintained leaves (LM) in relation to cuttings length at 120 days after planting.

\begin{tabular}{ccccccccc}
\hline Cutting length $\mathbf{( c m})$ & RC & NR & ARL & C & CRC & M & S & LM \\
\hline $\mathbf{2}$ & $71.25 \mathrm{ab}$ & $3.85 \mathrm{~b}$ & $1.45 \mathrm{~b}$ & $25.00 \mathrm{~cd}$ & $70.00 \mathrm{ab}$ & $1.25 \mathrm{~b}$ & $28.75 \mathrm{ab}$ & $96.25 \mathrm{ab}$ \\
$\mathbf{4}$ & $71.25 \mathrm{ab}$ & $2.66 \mathrm{~b}$ & $1.53 \mathrm{ab}$ & $27.50 \mathrm{~cd}$ & $71.25 \mathrm{ab}$ & $1.25 \mathrm{~b}$ & $30.0 \mathrm{ab}$ & $97.50 \mathrm{a}$ \\
$\mathbf{6}$ & $57.50 \mathrm{bc}$ & $3.21 \mathrm{~b}$ & $1.40 \mathrm{~b}$ & $41.25 \mathrm{bc}$ & $53.75 \mathrm{~b}$ & $1.25 \mathrm{~b}$ & $46.25 \mathrm{a}$ & $93.75 \mathrm{ab}$ \\
$\mathbf{8}$ & $37.50 \mathrm{cb}$ & $3.17 \mathrm{~b}$ & $1.68 \mathrm{ab}$ & $55.00 \mathrm{~b}$ & $27.5 \mathrm{c}$ & $7.50 \mathrm{a}$ & $28.75 \mathrm{ab}$ & $87.50 \mathrm{ab}$ \\
$1 \mathbf{1 0}$ & $86.25 \mathrm{a}$ & $7.37 \mathrm{a}$ & $2.42 \mathrm{a}$ & $13.75 \mathrm{~d}$ & $83.75 \mathrm{a}$ & $0.00 \mathrm{~b}$ & $51.25 \mathrm{a}$ & $98.75 \mathrm{a}$ \\
$\mathbf{1 2}$ & $22.50 \mathrm{~d}$ & $2.69 \mathrm{~b}$ & $2.0 \mathrm{ab}$ & $77.50 \mathrm{a}$ & $22.5 \mathrm{c}$ & $0.00 \mathrm{~b}$ & $13.75 \mathrm{~b}$ & $85.00 \mathrm{~b}$ \\
\hline Average & $57.7 \mathrm{I}$ & 3.82 & 1.75 & 40 & 54.79 & 1.87 & 33.13 & 93.13 \\
\hline
\end{tabular}

The averages followed by the same letter do not differ statistically from each other by the Tukey test ( $5 \%$ probability level)

Maintaining juvenile shoots in the field through continuous pruning is one of the factors that favor good rooting of yerba mate cuttings (SANTIN et al., 2008). Pruning can be done at different times of the year, keeping in mind that frosts can damage young branches that are still herbaceous. However, some authors recommend drastic pruning of yerba mate between July and August (winter), when the plant is in physiological rest (MEDRADO et al., 2002; SANTIN et al., 2008), which coincides with the harvest time of commercial plantations.

Another important factor concerning the establishment conditions of parent plants is shading, which favors etiolation and delays branch lignification (CÉSAR et al., 20I4). The effect of shading proved to be preponderant for rooting of Psidium guajava stem cuttings (COSTA JR et al., 2003). Etiolation can cause variations of anatomical characteristics for materials under shading conditions, including a greater number of parenchyma cells and the reduction of mechanical barriers (HARTMANN et al., 20II).

We note that the propagules used in this study were non-rejuvenated, however, they had high natural propensity for rooting due to the invigorating effect of pruning performed every two years on parent plants. We also highlight the potential of these parent plants in the formation of clonal gardens, possibly increasing percentages of root formation, since the more juvenile the plant material, the greater its vigor and ease of rooting (XAVIER et al., 20I3). Another positive factor concerns the high rhizogenic potential of the studied material, which does not require exogenous sources of auxin to root cuttings.

Several studies have been developed to verify the influence of cutting length on the root formation and plant quality of forest species. In a study developed by Oliveira et al. (2008), the authors observed that $10 \mathrm{~cm}$ cuttings of Melaleuca alternifolia were more effective for rooting when compared with 15 and $20 \mathrm{~cm}$ cuttings. In this sense, we note that our results for 2 and $4 \mathrm{~cm}$ cuttings both had high rooting percentages (7I.2\%). This is an important factor to consider for species propagation, since with smaller sized propagules there is a considerable increase in plants production.

The length of the cuttings directly influenced the number of adventitious roots formed, with more roots in $10 \mathrm{~cm}$ cuttings and an average of 7.4 roots per cutting (Table 2). In relation to the length of the three largest roots, we observed that cuttings with $10 \mathrm{~cm}$ were statistically higher than the others, presenting a mean of $2.4 \mathrm{~cm}$ (Table 2). These two factors are important when considering plants production and quality, since the more developed the root system, the higher the seedling quality and potential for development in the field.

Callus formation was observed in all treatments, being more expressive in the $12 \mathrm{~cm}$ cuttings (77.5\%). We observed root and callus formation on the same cutting for all evaluated lengths, ranging from $22.5 \%$ to $83.7 \%$ for cuttings of $12 \mathrm{~cm}$ and $10 \mathrm{~cm}$, respectively (Table 2). Although other authors have discussed callus formation as a detrimental effect on rooting of yerba mate cuttings (TRONCO et al., 20I5), we found that the presence of callus was not harmful for adventitious rooting, since treatments with highest rooting percentages presented callus formation. Further, it is important to emphasize that callus presence is not a determining condition for root formation, which may be a characteristic of each species (STUEPP et al., 20I3). 
The percentage of cuttings mortality was small for all treatments, highest in $8 \mathrm{~cm}$ cuttings $(7.5 \%)$, and below I.2\% for the other lengths (Table 2). These results are considered satisfactory to produce clonal plants of yerba mate and can be attributed to using semi-hardwood stem cuttings with characteristics suitable for rooting and photosynthetically active stems (Figure I). According to Dias et al. (20I5) the more tender the material used to make cuttings, the more sensitive the plant tissues will be, with higher chances of this material suffering under high temperatures and low humidity inside the greenhouses, leading to mortality.

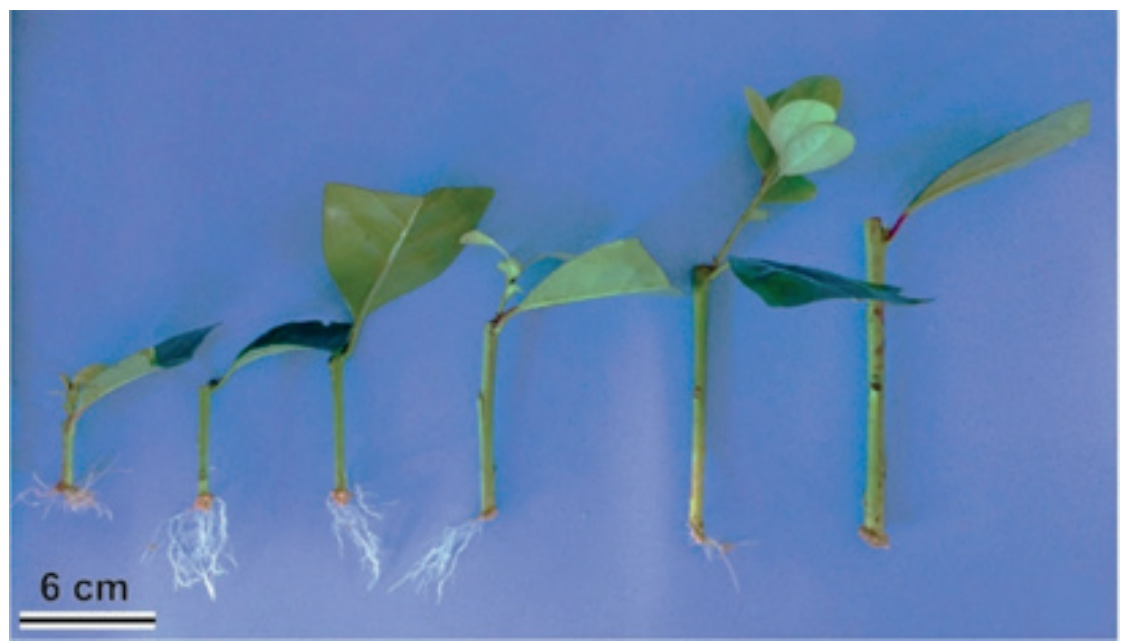

\section{Figure I}

General characterization of Ilex paraguariensis stem cuttings with $2,4,6,8,10$, and $12 \pm 0.2$ $\mathrm{cm}$ (from left to right) rooted after 120 days in greenhouse.

Similar to rooting, the emission of new shoots was higher for $10 \mathrm{~cm}$ cuttings $(51.2 \%)$, without significant difference in relation to those with $6 \mathrm{~cm}$ (46.25\%), and only higher than $12 \mathrm{~cm}$ cuttings (Table 2). According to Xie et al. (20l3), leaf and shoot emissions in cuttings are mediated by chemical signals synthesized in the roots, indicating favoring emission of new sprouts in $10 \mathrm{~cm}$ cuttings, which presented greater root vigor. We emphasize that other factors can influence the emission of new sprouts in cuttings, including the presence of axillary buds, the use of plant growth regulators, temperature, phytosanity of parent plants, and availability of carbohydrates capable of supplying energy for emission and development of sprouts (SOMKUWAR et al., 20I I).

We verified a high percentage of leaf maintenance in all cuttings lengths, with the lowest average for $12 \mathrm{~cm}$ cuttings, which presented the original leaves in $85 \%$ of the propagules. Leaves favor adventitious root formation (HARTMANN et al., 20II) as they are a source of hormones and carbohydrates that are essential for rhizogenesis (XAVIER et al., 20I3). Carbohydrates have no effective regulatory function in rooting but provide the energy necessary to synthesize other essential substances that induce rooting, and may favor the effect of auxins, hormones directly related to adventitious root emission (HARTMANN et al., 20I I).

Thus, our results showed an influence of propagules length on the formation of adventitious roots and that cuttings technique was efficient for yerba mate clonal plants production. Furthermore, although the plant material came from adult individuals ( $>50$-year-old), we infer that successive prunings of these plants made shoot material suitable for vegetative propagation, indicating the possibility of consistent rooting percentages using adult plant material of yerba mate.

\section{Conclusion}

Under the experimental conditions herein we concluded that rooting and root vigor in llex paraguariensis stem cuttings are influenced by the length of the cuttings, with a length of $10 \mathrm{~cm}$ being most efficient for rooting and vigor of the cuttings.

\section{Acknowledgments}

To Chimarrão Bitumirim Ind. de Erva-Mate Ltda., for all the support in conducting this experiment. 


\section{References}

BITENCOURT, J.; ZUFFELLATO-RIBAS, K. C.; WENDLING, I.; KOEHLER, H. Enraizamento de estacas de erva-mate (Ilex paraguariensis A. St.-Hill.) provenientes de brotações rejuvenescidas. Revista Brasileira de Plantas Medicinais, v. I, n.3, p.277-28I, 2009.

BRONDANI, G. E.; WENDLING, I.; ARAÚJO, M. A.; SANTIN, D.; BENEDETTI, E. L.; ROVEDA, L. F. Composições de substratos e ambientes de enraizamento na estaquia de llex paraguariensis A. St.-Hil. Revista Floresta, Curitiba, v.39, p.4I-49, 2009.

CÉSAR, F. R. C. F.; MATSUMOTO, S. N.; VIANA, A. E. S.; BONFIM, J. A. Crescimento inicial e qualidade de mudas de Pterogyne nitens Tull conduzidas sob diferentes níveis de restrição luminosa artificial. Ciência Florestal, v.24, n.2, p.357-366, 2014.

COSTA JR., W. H. D.; SCARPARE FILHO, J. A.; BASTOS, D. C. Estiolamento da planta matriz e uso de ácido indol butírico no enraizamento de estacas de goiabeiras. Revista Brasileira de Fruticultura, v.25, n.2, p.30I-304, 2003.

DIAS, P. C.; ATAÍDE, G. M.; XAVIER, A.; OLIVEIRA, L. S.; PAIVA, H. N. Propagação vegetativa de Schizolobium amazonicum por estaquia. Cerne, v.2I, n.3, p. 379-386, 2015.

FOSTER, G. S.; STELZER, H. E.; MCRAE, J. B. Loblolly pine cutting morphological traits: effects on rooting and field performance. New Forests, v. 19, p.29I - 306, 2000.

FOWLER, J. A. P.; STURION, J. A.; ZUFFELLATO-RIBAS, K. C. Variação do desenvolvimento embrionário das sementes de erva-mate. Pesquisa Florestal Brasileira, n.54, p. 105-108, 2007.

haRTMANN, H. T.; KeRSTER, D. E.; DAVIES JR., F. T.; GENEVE, R. L. Plant Propagation: principles and practices. 8 ed. Boston: Prentice Hal, 20II.

INSTITUTO BRASILEIRO DE GEOGRAFIA E ESTATÍSTICA - IBGE. Produção da Extração Vegetal e da Silvicultura 2016. Rio de Janeiro, v.30, p.I-48, 2016.

INSTITUTO BRASILEIRO DE GEOGRAFIA E ESTATÍSTICA - IBGE. Sistema IBGE de Recuperação Automática - SIDRA. Produção Agrícola Municipal - PAM - 2016. Disponível em: <https://sidra.ibge.gov.br/tabela/5457\#resultado>. Acesso em 10 dez. 2017.

KRATZ, D.; WENDLING, I.; PIRES, P. P., STUEPP, C. A. Produção de mudas de erva-mate por miniestaquia em substratos renováveis. Revista Floresta, v.45, n.3, p.609-616, 2015.

MEDRADO, M.J. S.; DALZOTO, D. N.; OLIZESKI, A.; MOSELE, S. H. Recuperação de ervais degradados. Colombo: Embrapa Florestas, 2002. (Embrapa Florestas. Comunicado técnico, 86).

MINISTÉRIO DA INDÚSTRIA, COMÉRCIO EXTERIOR E SERVIÇOS - MDIC. Sistema de Análise das Informações de Comércio Exterior via Internet. Disponível em: < http://aliceweb.mdic.gov.br>. Acesso em 10 dez. 2017.

OLIVEIRA, Y.; SILVA, A. L. L.; PINTO, F.; QUOIRIN, M.; BIASI, L. A. Comprimento das estacas no enraizamento de Melaleuca. Scientia Agraria, v.9, n.3, p.415-418, 2008.

RAKOCEVIC, M.; MEDRADO, M. J. S.; LUCAMBIO, F.; VALDUGA, T. A. Influência do sexo, da sombra e da idade de folhas no sabor do chimarrão. Análise, v.8, p. 10, 2006.

SANTIN, D.; WENDLING, I.; BENEDETTI, E. L.; MORANDI, D.; DOMINGOS, D. M. Sobrevivência, crescimento e produtividade de plantas de erva-mate produzidas por miniestacas juvenis e por sementes. Ciência Florestal, v.25, n.3, p.57I-579, 2015.

SANTIN, D.; WENDLING, I.; BENEDETTI, E. L.; BRONDANI, G. E.; REISSMANN, D. M.; ROVEDA, L. F. Poda e anelamento em erva-mate (llex paraguariensis) visando à indução de brotações basais. Pesquisa Florestal Brasileira, n.56, p.97-104, 2008.

SILVA, F. A. S.; AZEVEDO, C. A. V. The Assistat Software Version 7.7 and its use in the analysis of experimental data. African Journal of Agricultural Research, v.l I, n.39, p.3733-3740, 2016.

SOMKUWAR, R. G.; BONDAGE, D. D.; SURANGE, M. S.; RAMTEKE, S. D. Rooting behavior, polyphenol oxidase activity, and biochemical changes in grape rootstocks at different growth stages. Turkish Journal of Agriculture and Forestry, v.35, n.3, p.28I-287, $20 \mathrm{II}$. 
STUEPP, C. A.; BITENCOURT, J.; WENDLING, I.; KOEHLER, H. S.; ZUFFELLATO-RIBAS, K. C. Propagação de ervamate utilizando brotações de anelamento e decepa em matrizes de duas idades. Revista Cerne, v.21, n.4, p.5।9-526, 2015.

STUEPP, C. A.; BITENCOURT, J.; WENDLING, I.; KOEHLER, H. S.; ZUFFELLATO-RIBAS, K. C. Age of stock plants, seasons and iba effect on vegetative propagation of llex paraguariensis. Revista Árvore, v.4I, n.2, 20 I7a.

STUEPP, C. A.; BITENCOURT, J.; WENDLING, I.; KOEHLER, H. S.; ZUFFELLATO-RIBAS, K.C. Métodos de resgate e idades cronológicas de plantas-matrizes no enraizamento de brotações epicórmicas de llex paraguariensis. Ciência Florestal, v.27, n.4, p. 1409-1413, 2017b.

STUEPP, C. A.; PEREIRA, G. P.; ZEM, L. M.; PEÑA, M. L.; BUENO, P. M. C.; SPADER, V.; ZUFFELLATO-RIBAS, K. C.; ROSA, G. M. Enraizamento de melaleuca: influência da altura de coleta das estacas e aplicação de IBA. Colloquium Agrariae, v. 9, p. 01-09, 2013.

STURION, J. A.; STUEPP, C. A.; WENDLING, I. Genetic parameters estimates and visual selection for leaves production in Ilex paraguariensis. Bragantia, v. 76, n. 4, p. 492-500, 2017.

TRONCO, K. M. Q.; BISOGNIN, D. A. FLEig, F. D.; HORBACH, M. A. Enraizamento ex vitro e aclimatização de microestacas de llex paraguariensis A. St Hil. Cerne, v.2I, n.3, p.37I-378, 20 I 5.

VIDOR, M. A.; RUIZ, C. P.; MORENO, S. V.; FLOSS, P. A. Variabilidade genética em um ensaio de progênies de ervamate (llex paraguariensis St.-Hil.). Ciência Rural, v. 32, p. 583-587, 2002.

WENDLING, I.; BRONDANI, G. Vegetative rescue and cuttings propagation of Araucaria angustifolia. Revista Árvore, v. 39, n. I, p. 93-104, 2015.

XAVIER, A.; WENDLING, I.; SILVA, R. L. Silvicultura clonal: princípios e técnicas. 2. ed. Viçosa: Ed. UFV, 2013.

XIE, Z.; GUO, X.; CAO, H. Effect of root restriction on vegetative growth and leaf anatomy of 'Kyoho' grapevines cultivar. African Journal of Agricultural Research, v. 8, n. I5, p. I304-I 309, 2013. 